\title{
Synchronization of oestrus in adult female rats by utilizing the paradoxical effects of an LH-RH agonist
}

\author{
B. H. Vickery and G. I. McRae \\ Department of Physiology, Institute of Biological Sciences, Syntex Research, \\ 3401 Hillview Avenue, Palo Alto, California 94304, U.S.A.
}

\begin{abstract}
Summary. Implantation of $25 \mu \mathrm{g}$ per rat of an LH-RH agonist, [Des-Gly ${ }^{10}, \mathrm{D}$ $\mathrm{Ala}^{6}$, ProNHEt $\left.^{9}\right] \mathrm{LH}-\mathrm{RH}$, contained within a cholesterol matrix pellet caused a complete and continued suppression of oestrus in rats within 3 days. Removal of the pellets after 7 days led to synchronized oestrus 4 days later in $90-95 \%$ of the animals $(\mathrm{N}=30)$; the remaining animals became oestrous on the 5 th day. Fertility of these treated rats mated at the synchronized oestrus was equivalent to that of a control, sham-operated population allowed to mate over a 3-day period.
\end{abstract}

\section{Introduction}

The induction of a synchronous oestrus and ovulation resulting in a high level of fertility has long been the goal of agricultural researchers. Early work concentrated on the use of progestational steroids to delay ovulation to a fixed time point, essentially by increasing cycle length (Jöchle, 1972). Unfortunately the conception rates in cattle resulting from natural or artificial service at the synchronized oestrus were low (Trimberger \& Hansel, 1955). Prostaglandins (PGs), particularly those of the F series, have been shown to be luteolytic in many animals (Cooper, Hammond, Harker \& Jackson, 1976; Lagar, 1977) and synchronized oestrus occurs after inhibition of progesterone secretion from the corpus luteum and thus cycle length is decreased (Roche, 1974). Fertility is good following synchronization of oestrus with PG, reportedly equivalent to that for untreated cows mated at natural oestrus (Hearnshaw, 1976). However, the degree of synchrony is only 3-4 days (Cooper \& Furr, 1974) and this has led to the practice of two artificial inseminations at 72 and $96 \mathrm{~h}$ after treatment.

In the search for other agents with the potential ability to induce synchronization, it was noted that LH-RH agonists were capable of reversibly inhibiting ovulation in a variety of species (Johnson, Gendrich \& White, 1976; Fraser, 1979; McRae \& Vickery, 1979; Vickery \& McRae, 1980 ). In rats, the treatment also caused suppression of oestrus (McRae \& Vickery, 1979). As rats have previously been shown to provide a useful model for control of oestrus in larger species (Doyle \& Clegg, 1961; Hoffman \& Schwartz, 1965; Bennett, Vallance \& Vickery, 1968), we have examined the ability of a synthetic agonist of LH-RH to synchronize oestrus in rats.

\section{Materials and Methods}

Virgin randomly cyclic female albino rats (Simonsen, Gilroy, California) weighing 140-160 g were housed under $12 \mathrm{~h}$ light (06:00-18:00 h) $/ 24 \mathrm{~h}$ and allowed food and water ad libitum. 
Daily vaginal smears were taken each morning and examined to detect oestrus. The LH-RH agonist, [Des-Gly ${ }^{10}, \mathrm{D}-\mathrm{Ala}^{6}$, ProNHEt ${ }^{9}$ LH-RH, was formulated into compacted cholesterol matrix pellets containing $0 \cdot 1 \%(25 \mu \mathrm{g}) \mathrm{LH}-\mathrm{RH}$ agonist. The pellets were approximately $3 \times 3$ $\mathrm{mm}$ and weighed approximately $25 \mathrm{mg}$.

In Exp. 1, 10 rats in Group 1 each received one pellet of LH-RH agonist implanted subcutaneously in the nuchal area under ether anaesthesia. The rats in Group 2 were sham-operated but pellets were not implanted. After 7 days the rats were again anaesthetized and the pellets were removed from the treated rats; control rats were again sham-operated.

In Exp. 2 there were 20 females in each of Groups 1 and 2. Treatment was the same as in Exp. 1. The females from both groups were housed with mature male rats of proven fertility (2 females and 1 male per cage) on the 3rd, 4th and 5th days after pellet removal. Mating and behavioural oestrus were identified by detection of spermatozoa in the vaginal smear. The females were killed 14 days after mating and the numbers of implantation sites and viable fetuses were recorded.

\section{Results}

Implantation of pellets was followed by complete suppression of oestrus in all treated animals within 3 days. This suppression, characterized by a dioestrous smear, continued for the duration of treatment in contrast to sham-operated rats who cycled normally (Table 1). Oestrus was not detected in treated rats until the 4th day after removal of the pellets, and all the females had become oestrous by the 5th day. A significant synchronization of oestrus was thus obtained in the treated rats (Table 2).

Table 1. Number of rats in oestrus during and after a 7-day implantation of pellets containing $25 \mu \mathrm{g}$ LH-RH agonist

\begin{tabular}{|c|c|c|c|c|}
\hline \multirow[b]{2}{*}{ Day of study } & \multicolumn{2}{|c|}{ Experiment 1} & \multicolumn{2}{|c|}{ Experiment 2} \\
\hline & $\begin{array}{c}\text { Group 1 } \\
\text { Implanted } \\
(\mathrm{N}=10)\end{array}$ & $\begin{array}{c}\text { Group 2 } \\
\text { Sham-operated } \\
(\mathbf{N}=10)\end{array}$ & $\begin{array}{c}\text { Group 1 } \\
\text { Implanted } \\
(\mathrm{N}=20)\end{array}$ & $\begin{array}{c}\text { Group 2 } \\
\text { Sham-operated } \\
(\mathrm{N}=20)\end{array}$ \\
\hline $0^{*}$ & 1 & 2 & 2 & 4 \\
\hline 1 & 0 & 1 & 6 & 3 \\
\hline 2 & 0 & 3 & 1 & 4 \\
\hline 3 & 0 & 4 & 0 & 3 \\
\hline 4 & 0 & 2 & 0 & 7 \\
\hline 5 & 0 & 2 & 0 & 3 \\
\hline 6 & 0 & 1 & 0 & 5 \\
\hline $7 \dagger$ & 0 & 4 & 0 & 4 \\
\hline 8 & 0 & 3 & 0 & 5 \\
\hline 9 & 0 & 1 & 0 & 4 \\
\hline 10 & 0 & 2 & $0 \ddagger$ & $6 \ddagger$ \\
\hline 11 & 9 & 4 & $17 \ddagger$ & $6 \ddagger$ \\
\hline 12 & 1 & 1 & $3 \ddagger$ & $4 \ddagger$ \\
\hline 13 & 0 & 3 & 0 & 3 \\
\hline 14 & 0 & 2 & 1 & 0 \\
\hline 15 & 9 & 4 & 1 & 0 \\
\hline 16 & 1 & 1 & 0 & 0 \\
\hline 17 & 0 & 2 & 0 & 4 \\
\hline 18 & 0 & 3 & 0 & 0 \\
\hline 19 & 9 & 4 & 1 & 0 \\
\hline
\end{tabular}

* Day of pellet implantation.

$\dagger$ Day of pellet removal.

¥ Females housed with males. 
Table 2. Percentages of rats in oestrus after a 7-day implantation of pellets containing $25 \mu \mathrm{g} \mathrm{LH-RH}$ agonist (combining results of Exp. 1 and Exp. 2)

\begin{tabular}{lcrrrrrr}
\hline & \multicolumn{5}{c}{ Days after pellet removal } \\
\cline { 3 - 7 } \multicolumn{1}{c}{ Treatment group } & No. of rats & \multicolumn{1}{c}{0} & \multicolumn{1}{c}{1} & \multicolumn{1}{c}{2} & 3 & 4 & 5 \\
\hline Sham-operated & 30 & 27 & 27 & 17 & 27 & $33^{*}$ & 17 \\
Implanted with LH-RH analogue & 30 & 0 & 0 & 0 & 0 & $87^{*}$ & 13 \\
\hline
\end{tabular}

${ }^{*} P<0.01$ by $\chi^{2}$ test.

The occurrence of mating and fertility in rats in Exp. 2 is reported in Table 3. Vaginal oestrus was accompanied by behavioural oestrus with fertility equivalent to that of sham-operated rats, as based on implantation sites and viable fetuses.

Table 3. Mating and fertility in female rats housed with males during synchronous oestrus induced by a 7-day implantation of pellets containing $25 \mu \mathrm{g} \mathrm{LH}-\mathrm{RH}$ agonist

\begin{tabular}{|c|c|c|c|c|c|c|}
\hline \multirow[b]{2}{*}{ Treatment } & \multirow{2}{*}{$\begin{array}{l}\text { No. of } \\
\text { rats }\end{array}$} & \multirow{2}{*}{$\begin{array}{l}\% \text { rats } \\
\text { mated }^{*}\end{array}$} & \multirow{2}{*}{$\begin{array}{c}\% \text { rats with } \\
\text { implantation sites }\end{array}$} & \multirow{2}{*}{$\begin{array}{c}\% \text { rats with } \\
\text { viable fetuses }\end{array}$} & \multicolumn{2}{|c|}{ Mean \pm s.e.m. no. of fetuses $\dagger$} \\
\hline & & & & & Viable & Non-viable \\
\hline Sham-operated & 20 & 80 & 80 & 75 & $11.0 \pm 0.6$ & $3.4 \pm 1.7$ \\
\hline $\begin{array}{l}\text { Implanted with } \\
\text { LH-RH analogue }\end{array}$ & 20 & 95 & 85 & 75 & $10 \cdot 9 \pm 1 \cdot 2$ & $2.7 \pm 0.7$ \\
\hline
\end{tabular}

\footnotetext{
* Rats showing spermatozoa in vaginal smear and/or signs of implantation at death.

$\uparrow$ Per pregnant rat.
}

\section{Discussion}

These results show that subcutaneous implantation of an agonist of LH-RH in the form of a cholesterol pellet is effective in suppressing vaginal oestrus in rats, confirming a previous report (McRae \& Vickery, 1979). Fertility is normal at the oestrus which occurs within 4-5 days after withdrawal of treatment. The result is perhaps surprising in view of the degree of ovarian and uterine weight suppression and the decrease in gonadal gonadotrophin receptors previously reported to be associated with administration of such agents (Kledzik, Cusan, Auclair, Kelly \& Labrie, 1978). The depletion of gonadal gonadotrophin receptors has been shown to be associated with elevated levels of gonadotrophin (Conti, Harwood, Hsueh, Dufau \& Catt, 1976). However, continuous administration of these agents from this pellet formulation does not induce persistent high levels of circulating gonadotrophins (McRae \& Vickery, 1979; Vickery \& McRae, 1980). This rapid reversal of the blockade of ovulation therefore lends substance to the previous suggestions that more than one mechanism might be involved in the paradoxical effects of these agents (Rivier, Rivier \& Vale, 1978; Tcholakian et al., 1978). These possibilities include extra-pituitary actions of the LH-RH agonists, such as direct gonadal effects. Studies on the effect of these agents both in vitro and in vivo in hypophysectomized animals support the latter possibility (Hsueh \& Erickson, 1979; MacDonald \& Beattie, 1979; Ying \& Guillemin, 1979).

The successful induction of fertile, synchronized oestrus in the laboratory rat by use of an LH-RH agonist suggests that the effects of such agonists in cattle and pigs should be investigated.

We thank Dr R. A. Edgren for critical review of the manuscript. 


\section{References}

Bennett, J.P., Vallance, D.K. \& Vickery, B.H. (1968) The synchronization of ovulation in the adult female rat by oral administration of megestrol acetate. $J$. Reprod. Fert. 16, 159-163.

Conti, M., Harwood, J.P., Hsueh, A.J.W., Dufau, M.L. \& Catt, K.H. (1976) Gonadotrophin-induced loss of hormone receptors and desensitization of adenylate cyclase in the ovary. J. biol. Chem. 251, 7729-7731.

Cooper, M.J. \& Furr, B.J.A. (1974) The role of prostaglandins in animal breeding. Vet. Rec. 94, 161.

Cooper, M.J., Hammond, D., Harker, D.B. \& Jackson, P.S. (1976) Control of the bovine estrous cycle with ICI 80,996 (Cloprostenol). Field results in 3,810 beef cattle. Proc. 8th Int. Congr. Anim. Reprod. \& A.I., Cracow 3, 449-451.

Doyle, D.L. \& Clegg, M.T. (1961) Effect of progesterone withdrawal on time of oestrus and mating behaviour in female rats. J. Reprod. Fert. 2, 143-147.

Fraser, H.M. (1979) Inhibition of ovulation in the monkey (Macaca arctoides) by chronic treatment with an agonist of LH-RH. Acta endocr., Copenh., Suppl. 225, 136, Abstr.

Hearnshaw, H. (1976) Synchronization of oestrus and subsequent fertility in cattle, using the prostaglandin $\mathrm{F}_{2} \alpha$ analogue, ICI 80996 (Cloprostenol). Aust. J. exp. Agric. Anim. Husb. 16, 437-444.

Hoffman, J.C. \& Schwartz, N.B. (1965) Timing of ovulation following progesterone withdrawal in the rat. Endocrinology 76, 625-631.

Hsueh, A.J.W. \& Erickson, G.F. (1979) Extrapituitary action of gonadotrophin-releasing hormone: direct inhibition of ovarian steroidogenesis. Science, N.Y. 204, 854-855.

Jöchle, W. (1972) Pharmacological aspects of the control of the cycle in domestic animals. Proc. 6th Int. Congr. Anim. Reprod. \& A.I., Munich 1, 97-124.

Johnson, E.S., Gendrich, R.L. \& White, W.F. (1976) Delay of puberty and inhibition of reproductive processes in the rat by a gonadotrophin releasing hormone agonist analog. Fert. Steril. 27, 853-860.

Kledzik, G.S., Cusan, L., Auclair, C., Kelly, P.A. \& Labrie, F. (1978) Inhibition of ovarian luteinising hormone (LH) and follicle-stimulating hormone receptor levels with an LH-releasing hormone agonist during the estrous cycle in the rat. Fert. Steril. 30, 348-353.

Lagar, J.J. (1977) Synchronization of the estrous cycle with prostaglandin $\mathrm{F}_{2} \boldsymbol{\alpha}$ for use of artificial insemination in cattle (a review). Vet. Med. Small Anim. Clin. 72, 87-92.

MacDonald, G.J. \& Beattie, C.W. (1979) Pregnancy failure in hypophysectomized rats following $\mathrm{LH}-\mathrm{RH}$ administration. Life Sciences 27, 1103-1110.

McRae, G.I. \& Vickery, B.H. (1979) Effect of chronic administration of Des Gly ${ }^{10}$ DAla $^{6}$ ProNHEt ${ }^{9}$ LHRH (LHRH-A) to female rats. Endocrinology 104, 182A, Abstr.

Rivier, C., Rivier, J. \& Vale, W. (1978) Chronic effects of [D-Trp ${ }^{6}$-Pro'-NEt]luteinizing hormone-releasing factor on reproductive processes in the female rat. Endocrinology 103, 2299-2305.

Roche, J.F. (1974) Synchronization of oestrus and fertility following artificial insemination in heifers given prostaglandin $\mathrm{F}_{2} \alpha J$. Reprod. Fert. 37, 135138.

Tcholakian, R.K., De La Cruz, A., Chowdhury, M., Steinberger, A., Coy, D.H. \& Schally, A.V. (1978) Unusual anti-reproductive properties of the analog [D-Leu ${ }^{6}$, Des-Gly- $\mathrm{NH}_{2}{ }^{10}$ ]-luteinizing hormone-releasing hormone ethylamide in male rats. Fert. Steril. $30,600-603$.

Trimberger, G.W. \& Hansel, W. (1955) Conception rate and ovarian function following oestrus control by progesterone injections in dairy cattle. J. Anim. Sci. 14, 224-232.

Vickery, B.H. \& McRae, G.I. (1980) Effects of continuous treatment with super-agonists of LHRH when initiated at different times of the menstrual cycle in female baboons. Int. J. Fert. (in press).

Ying, S.-H. \& Guillemin, R. (1979) (DTrp6 ${ }^{6}$-Pro'-NEt)luteinising hormone-releasing factor inhibits follicular. development in hypophysectomized rats. Nature, Lond. 280, 593-595. 